\title{
Desulfosporosinus youngiae sp. nov., a spore- forming, sulfate-reducing bacterium isolated from a constructed wetland treating acid mine drainage
}

Correspondence Juergen Wiegel jwiegel@uga.edu

\author{
Yong-Jin Lee, ${ }^{1,3}$ Christopher S. Romanek ${ }^{2,3}$ and Juergen Wiegel ${ }^{1}$ \\ 1 Department of Microbiology, University of Georgia, Athens, GA 30602, USA \\ ${ }^{2}$ Department of Geology, University of Georgia, Athens, GA 30602, USA \\ ${ }^{3}$ Savannah River Ecology Laboratory, Aiken, SC 29802, USA
}

Sulfate-reducing bacteria (SRB) are responsible for a variety of biogeochemical processes. For example, SRB reduce sulfate to dissolved sulfide $\left(\mathrm{S}^{2-}\right)$, which may react with metals to form metal sulfides; thus, they are considered to play a major role in metal removal and alkalinity generation in treating acid mine drainage. The SRB are an ecologically and metabolically diverse group of anaerobes which include members of the phylum Firmicutes (formerly the phylogenetically Gram-type-positive bacteria; Wiegel, 1981) residing within the family Peptococcaceae in the order Clostridiales. Among them, the genus Desulfosporosinus currently consists of five species of obligately anaerobic, spore-forming bacteria (http:// www.bacterio.cict.fr/d/desulfosporosinus.html). Stackebrandt et al. (1997) distinguished this group from the genus Desulfotomaculum on the basis of phylogenetic evidence and their ability to grow under autotrophic conditions.

Abbreviation: SRB, sulfate-reducing bacteria.

The GenBank/EMBL/DDBJ accession number for the 16S rRNA gene sequence of strain JW/YJL-B18 ${ }^{\top}$ is DQ117470.
However, the property of autotrophic growth (i.e. $50 \%$ of the biomass is derived from inorganic carbon) has not been demonstrated unequivocally for all species. Vatsurina et al. (2008) recently reported Desulfosporosinus orientis 343 as the type strain of a novel species in the same genus, Desulfosporosinus hippei, which does not oxidize $\mathrm{H}_{2}$ with $\mathrm{CO}_{2}$ or acetate. Here, we report another novel Desulfosporosinus species that is not capable of growing lithotrophically, isolated from a constructed treatment wetland receiving acid mine drainage.

A sediment sample was taken from a constructed treatment wetland receiving acid sulfate water (Lee et al., 2006) and inoculated into the medium for enrichment prepared as described by Widdel \& Bak (1992). The medium contained lactate $(15 \mathrm{mM})$ as the main carbon and energy source and was supplemented with $0.05 \%$ yeast extract. The $\mathrm{pH}^{25}{ }^{\circ} \mathrm{C}$ of the medium was 6.8. The enrichment culture was incubated at $37^{\circ} \mathrm{C}$ for 4 weeks. Two isolates, designated strains JW/YJL-B $18^{\mathrm{T}}$ and JW/YJL-B19, were obtained and purified by three subsequent rounds of single colony isolation using the agar $(1.5 \% \mathrm{w} / \mathrm{v})$-shake-roll-tube 
technique (Ljungdahl \& Wiegel, 1986). Colonies of both isolates appeared after 1-2 days in an agar-roll tube and were white, irregular and sometimes filamentous, 0.1$0.8 \mathrm{~mm}$ in diameter. The cells of both isolates were curved rods that typically measured $0.7-1.2 \mu \mathrm{m}$ in diameter and $3.0-7.0 \mu \mathrm{m}$ in length. Endospores detected in the late exponential growth phase were oval and central to subterminal. Cells stained Gram-negative at all growth phases.

DNA was extracted from the isolates as described previously (Lee et al., 2005) and the 16S rRNA gene was amplified with the primers 27 forward and 1492 reverse (Lane, 1991). PCR amplification and subsequent sequencing of $16 \mathrm{~S}$ rRNA genes were performed as described previously (Lee et al., 2007). The similarities of partial sequences were determined using Sequencher version 4.1.4 (Gene Codes). Retrieved 16S rRNA gene sequences were analysed using BLASTN, aligned with closely related sequences using CLUSTAL_X version 1.81 (Thompson et al., 1997) and edited using GeneDoc version 2.6.02 (http:// www.nrbsc.org/gfx/genedoc/). Phylogenetic trees were constructed using algorithms provided in PHYLIP version 3.6a2.1 (Felsenstein, 2001).

The nearly complete 16S rRNA gene sequences of strains JW/YJL-B18 ${ }^{\mathrm{T}}$ and JW/YJL-B19 were identical; thus, only strain JW/YJL-B $18^{\mathrm{T}}$ was chosen for further analyses because they were both isolated from the same enrichment culture. The 16S rRNA gene sequence consisting of 1443 bp (positions 52-1470 according to the Escherichia coli numbering scheme; GenBank accession no. X80725) placed strain JW/YJL-B $18^{\mathrm{T}}$ within the radius of the genus Desulfosporosinus (Stackebrandt et al., 1997). The closest relative identified was the unpublished Peptococcaceae strain Y5 $(99.8 \%$ similarity in the $16 \mathrm{~S}$ rRNA gene sequence) (Liu et al., 2004). The next closest neighbour was Desulfosporosinus auripigmenti OREX-4 ${ }^{\mathrm{T}}$, with $97.9 \%$ similarity (Fig. 1). DNA-DNA hybridization of strain JW/ YJL-B18 ${ }^{\mathrm{T}}$ against Desulfosporosinus auripigmenti DSM $13351^{\mathrm{T}}$ showed $3.1 \%(5.1 \%$ in duplicate $)$ relatedness, indicating that strain JW/YJL-B $18^{\mathrm{T}}$ does not belong to the species Desulfosporosinus auripigmenti based on the recommendations of Wayne et al. (1987).
Strain JW/YJL-B $18^{\mathrm{T}}$ grew at $8-39{ }^{\circ} \mathrm{C}$ at $\mathrm{pH} 7.0$, with an optimum at $32-35{ }^{\circ} \mathrm{C}$. No growth was detected at $4{ }^{\circ} \mathrm{C}$ or below or at $42{ }^{\circ} \mathrm{C}$ or above. The $\mathrm{pH}$ range for growth was $\mathrm{pH} 5.7-8.2$ at $35{ }^{\circ} \mathrm{C}$, with an optimum at $\mathrm{pH}$ 7.0-7.3. No growth was detected at or below $\mathrm{pH} 5.2$ or at or above $\mathrm{pH}$ 8.4. The salinity range for growth was $0-3 \%(\mathrm{w} / \mathrm{v})$ $\mathrm{NaCl}$ at a $\mathrm{NaCl} / \mathrm{KCl}$ ratio of $9: 1$. However, strain JW/YJL$\mathrm{B} 18^{\mathrm{T}}$ grew with up to $6 \% \mathrm{NaCl}$ when iron citrate $(0.1 \mathrm{mM})$ was added to the medium.

Utilization of various carbon sources was determined using the basal medium from Widdel \& Bak (1992) supplemented with $0.02 \%$ yeast extract. Strain JW/YJL-B18 ${ }^{\mathrm{T}}$ utilized beef extract $(0.2 \%)$, yeast extract $(0.2 \%)$, formate $(20 \mathrm{mM})$, succinate $(20 \mathrm{mM})$, lactate $(20 \mathrm{mM})$, pyruvate $(20 \mathrm{mM})$, ethanol $(20 \mathrm{mM})$ and toluene $(0.1 \mathrm{mM})$ as carbon and energy sources. There was no evidence of growth on Casamino acids, peptone, tryptone, acetate, arabinose, cellobiose, fructose, galactose, glucose, lactose, maltose, mannose, raffinose, sucrose, inositol, mannitol, sorbitol, xylitol, glutamate, propionate, benzene, phenol $(1 \mathrm{mM})$ or benzoate $(1 \mathrm{mM})$. Moreover, strain JW/YJL$\mathrm{B} 18^{\mathrm{T}}$ did not show evidence of growth under chemolithoautotrophic or chemolithoheterotrophic conditions, i.e. with $\mathrm{H}_{2} / \mathrm{CO}_{2}$ or $\mathrm{H}_{2}$ /arsenate/acetate (Liu et al., 2004). Utilization of electron acceptors was tested with $0.2 \%$ lactate as an electron donor, and the following electron acceptors at a concentration of $20 \mathrm{mM}$ were utilized: fumarate, forming succinate, and sulfate, thiosulfate and sulfite $(2 \mathrm{mM})$, forming sulfide. Arsenate, anthraquinone 2,6-disulfonate (AQDS), elemental sulfur, ferric citrate, ferric oxyhydroxide, manganese, nitrate, nitrite, nickel, molecular oxygen and selenium were not utilized as terminal electron acceptors. The inability of strain JW/ YJL-B $18^{\mathrm{T}}$ to reduce arsenate was further suggested by the failure to obtain a PCR product for the arsenate reductase gene (arrA) (Malasarn et al., 2004). Several other morphological and physiological characters separate the novel isolate from other Desulfosporosinus species (Table 1). Strains JW/YJL-B $18^{\mathrm{T}}$ and JW/YJL-B19 failed to yield a PCR product using primer sets for the $\alpha$-subunit of the adenosine- $5^{\prime}$-phosphosulfate reductase gene (apsA) and the dissimilatory sulfite reductase genes $(d s r A B)$ (Friedrich,

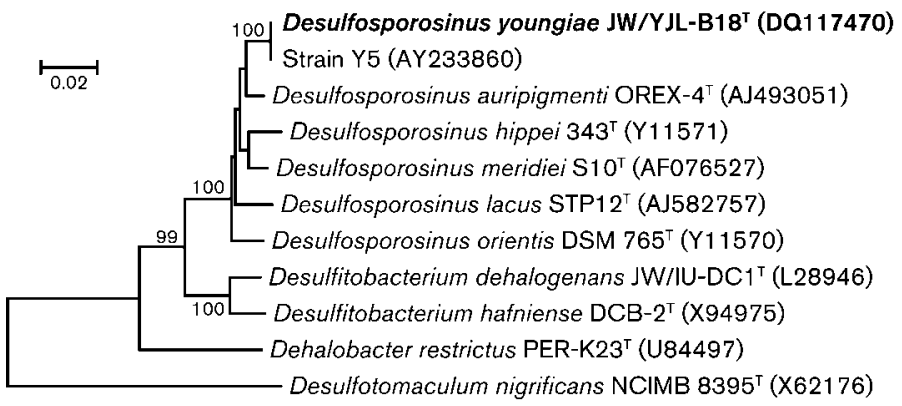

Fig. 1. Phylogenetic dendrogram based on 16S rRNA gene sequences showing the position of strain JW/YJL-B18 ${ }^{\top}$ amongst members of the genus Desulfosporosinus. The tree was constructed using the neighbour-joining method with Jukes and Cantor distance corrections. Numbers at nodes represent bootstrap values (percentages of 1000 replicates); values above $80 \%$ were considered significant. Bar, 2 substitutions per 100 nucleotide positions. 
Table 1. Biochemical and chemotaxonomic characteristics of strain JW/YJL-B18 ${ }^{\top}$ and its closest relatives

Strains: 1, JW/YJL-B18 ${ }^{\mathrm{T}}$ (this study); 2, Desulfosporosinus auripigmenti OREX-4 ${ }^{\mathrm{T}}$ (Newman et al., 1997; Stackebrandt et al., 2003); 3, Desulfosporosinus meridiei $10^{\mathrm{T}}$ (Robertson et al., 2001); 4, Desulfosporosinus orientis DSM $765^{\mathrm{T}}$ (Campbell \& Postgate, 1965; Stackebrandt et al., 2003); 5, Desulfosporosinus lacus STP12 $2^{\mathrm{T}}$ (Ramamoorthy et al., 2006); 6, Desulfosporosinus hippei $343^{\mathrm{T}}$ (Vatsurina et al., 2008). ND, No data available.

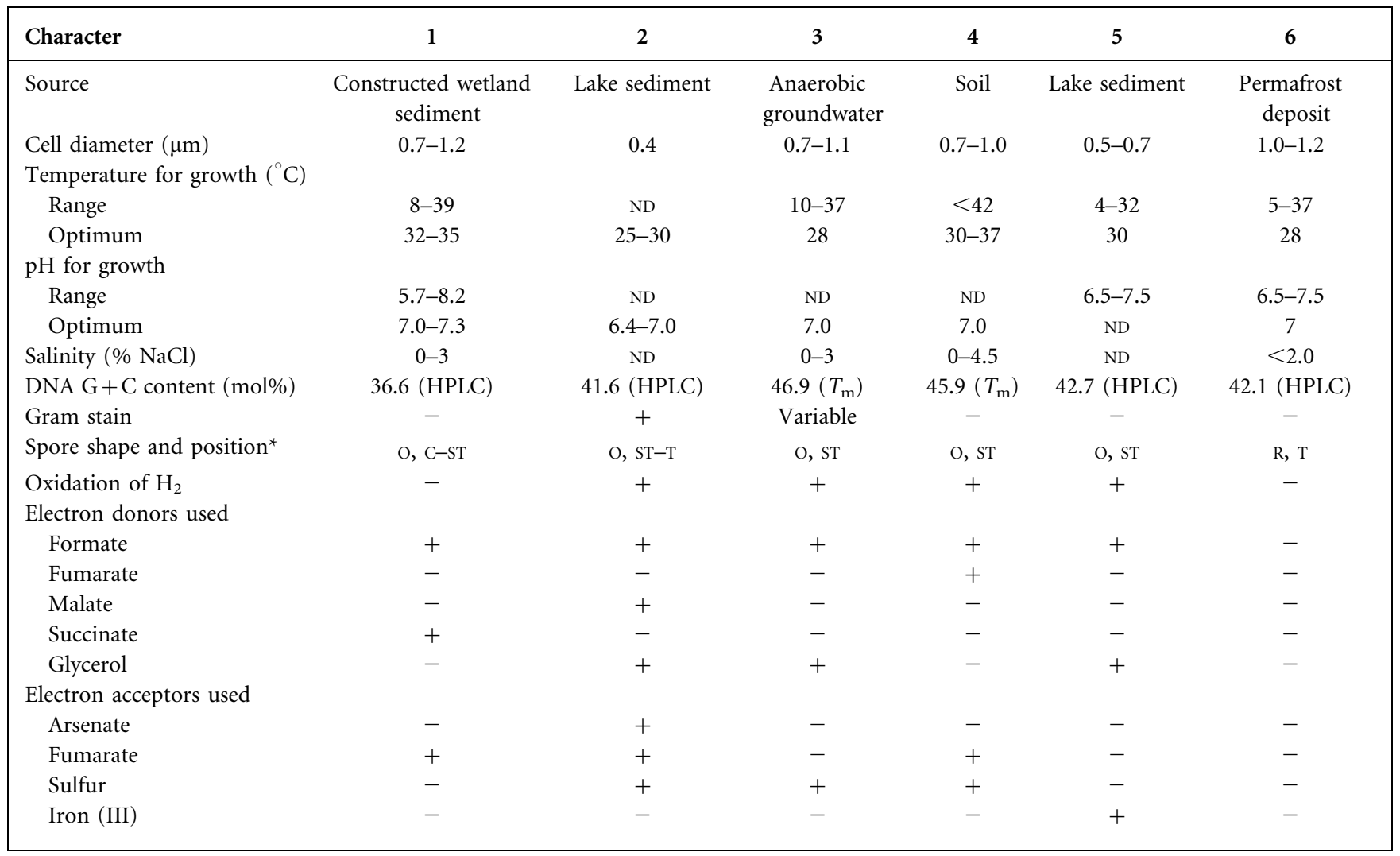

${ }^{*} \mathrm{C}$, Central; O, oval; R, round; ST, subterminal; T, terminal.

2002; Wagner et al., 1998). However, these results are probably due to deviations from consensus sequences in regions complementary to the two primer sets.

Bacterial cell-membrane phospholipid fatty acids were extracted, fractionated, saponified and methylated to obtain fatty acid methyl ester profiles of the phospholipids as described previously (Guckert et al., 1985). Fatty acid methyl esters were analysed using GC-MS (Agilent 7972 MSD) as described previously (Lee et al., 2006). The major fatty acids were the even-numbered carbon, straight-chain saturated and mono-unsaturated fatty acids $\mathrm{C}_{16: 0}$ and $\mathrm{C}_{16: 1}$, which together made up approximately $80 \%$ of the total phospholipid fatty acids. Other minor fatty acids were $\mathrm{C}_{14: 0}, \mathrm{C}_{15: 0}, \mathrm{C}_{16: 1} \omega 9 c, \mathrm{C}_{18: 1} \omega 9 c, \mathrm{C}_{18: 1} \omega 7 c$ and $\mathrm{C}_{18: 0}$. This distribution is similar to those of other members of the genus Desulfosporosinus (Ramamoorthy et al., 2006); however, strain JW/YJL-B18 ${ }^{\mathrm{T}}$ showed a much higher content of $\mathrm{C}_{16: 1} \quad(57.7 \%)$ compared with other Desulfosporosinus species (29-38\%). The G+C content of the genomic DNA was determined by the HPLC method as described previously (Mesbah et al., 1989; Lee et al.,
2005). The G+C content was 36.6 mol\% (mean of four replicates), which is lower than those reported for other species in the genus Desulfosporosinus (Table 1).

Based on evidence from this polyphasic study, including the inability to grow under chemolithoautotrophic conditions and the low genomic DNA $\mathrm{G}+\mathrm{C}$ content, we propose to place strain JW/YJL-B18 ${ }^{\mathrm{T}}$ into the novel taxon Desulfosporosinus youngiae sp. nov., belonging to the family Peptococcaceae (Garrity et al., 2004; Spring \& Rosenzweig, 2006).

\section{Description of Desulfosporosinus youngiae sp. nov.}

Desulfosporosinus youngiae (young'i.ae. N.L. fem. gen. n. youngiae of Young, in recognition of the contributions of Lily Y. Young to our understanding of the physiology and ecology of anaerobic bacteria).

Cells are curved rods, $0.7-1.2 \mu \mathrm{m}$ in diameter and 3.0$7.0 \mu \mathrm{m}$ long. Endospores are oval, central to subterminal. Cells stain Gram-negative but are phylogenetically Gramtype-positive (Wiegel, 1981), belonging to the phylum 
Firmicutes. The temperature range for growth is $8-39{ }^{\circ} \mathrm{C}$; optimum growth at $32-35{ }^{\circ} \mathrm{C}$ with no growth at $4{ }^{\circ} \mathrm{C}$ or below or at $42{ }^{\circ} \mathrm{C}$ or above. The $\mathrm{pH}^{25}{ }^{\circ}{ }^{\circ}$ range for growth is 5.7-8.2; optimum growth at $\mathrm{pH}^{25}{ }^{\circ} \mathrm{C} 7.0-7.3$, with no growth at or below $\mathrm{pH}^{25}{ }^{\circ} \mathrm{C} 5.2$ or at or above $\mathrm{pH}^{25}{ }^{\circ} \mathrm{C} 8.4$. The salinity range for growth is $0-3 \%(\mathrm{w} / \mathrm{v})(9: 1 \mathrm{NaCl} /$ $\mathrm{KCl})$. In the presence of $0.02 \%(\mathrm{w} / \mathrm{v})$ yeast extract, beef extract $(0.2 \%)$, yeast extract $(0.2 \%)$, formate, succinate, lactate, pyruvate, ethanol (all at $20 \mathrm{mM}$ ) and toluene $(0.1 \mathrm{mM})$ serve as carbon and energy sources. Fumarate, sulfate, sulfite and thiosulfate serve as electron acceptors. Arsenate, nitrate and iron (III) do not serve as electron acceptors. The predominant whole-cell fatty acids are $\mathrm{C}_{16: 1}$ $(\sim 58 \%)$ and $\mathrm{C}_{16: 0}(\sim 22 \%)$. The genomic DNA G+C content of the type strain is $36.6 \mathrm{~mol} \%$ (HPLC).

The type strain is JW/YJL-B18 ${ }^{\mathrm{T}}\left(=\mathrm{DSM} 17734^{\mathrm{T}}=\mathrm{ATCC}\right.$ BAA- $\left.1261^{\mathrm{T}}\right)$.

\section{Acknowledgements}

This research was partially supported by Financial Assistance Award Number DE-FC09-96SR18546 between the United States Department of Energy and the University of Georgia as a part of the US DOE National Water Research Center. We thank Robert C. Thomas for providing samples for this experiment, Gary L. Mills for lipid analysis and Jean P. Euzéby for his help with the nomenclature.

\section{References}

Campbell, L. L. \& Postgate, J. R. (1965). Classification of the sporeforming sulfate-reducing bacteria. Bacteriol Rev 29, 359-363.

Felsenstein, J. (2001). PHYLIP - (phylogeny inference package), version 3.6a2.1. Distributed by the author. Department of Genome Sciences, University of Washington, Seattle, USA.

Friedrich, M. W. (2002). Phylogenetic analysis reveals multiple lateral transfers of adenosine-5'-phosphosulfate reductase genes among sulfate-reducing microorganisms. J Bacteriol 184, 278-289.

Garrity, G. M., Bell, J. A. \& Lilburn, T. G. (2004). Taxonomic outline of the prokaryotes. In Bergey's Manual of Systematic Bacteriology, 2nd edn, release 5.0. New York: Springer. http://www.bergeys.org/ outlines/bergeysoutline_5_2004.pdf

Guckert, J. B., Antworth, C. P., Nichols, P. D. \& White, D. C. (1985). Phospholipid ester-linked fatty acid profiles as reproducible assays for changes in prokaryotic community structure of estuarine sediments. FEMS Microbiol Lett 31, 147-158.

Lane, D. J. (1991). 16S/23S rRNA sequencing. In Nucleic Acid Techniques in Bacterial Systematics, pp. 115-175. Edited by E. Stackebrandt \& M. Goodfellow. New York: Wiley.

Lee, Y.-J., Wagner, I. D., Brice, M. E., Kevbrin, V. V., Mills, G. L., Romanek, C. S. \& Wiegel, J. (2005). Thermosediminibacter oceani gen. nov., sp. nov. and Thermosediminibacter litoriperuensis sp. nov., new anaerobic thermophilic bacteria isolated from Peru Margin. Extremophiles 9, 375-383.

Lee, Y.-J., Romanek, C. S., Mills, G. L., Davis, R. C. \& Wiegel, J. (2006). Gracilibacter thermotolerans gen. nov., sp. nov., an anaerobic, thermotolerant bacterium from a constructed wetland receiving acid sulfate water. Int J Syst Evol Microbiol 56, 2089-2093.

Lee, Y.-J., Romanek, C. S. \& Wiegel, J. (2007). Clostridium aciditolerans sp. nov., an acid-tolerant spore-forming anaerobic bacterium from constructed wetland sediment. Int $J$ Syst Evol Microbiol 57, 311-315.

Liu, A., Garcia-Dominguez, E., Rhine, E. D. \& Young, L. Y. (2004). A novel arsenate respiring isolate that can utilize aromatic substrates. FEMS Microbiol Ecol 48, 323-332.

Ljungdahl, L. G. \& Wiegel, J. (1986). Anaerobic fermentations. In Manual of Industrial Microbiology and Biotechnology, pp. 84-96. Edited by A. L. Demain \& N. A. Solomon. Washington, DC: American Society for Microbiology.

Malasarn, D., Saltikov, C. W., Campbell, K. M., Santini, J. M., Hering, J. G. \& Newman, D. K. (2004). arrA is a reliable marker for $\mathrm{As}(\mathrm{V})$ respiration. Science 306, 455.

Mesbah, M., Premachandran, U. \& Whitman, W. B. (1989). Precise measurement of the $\mathrm{G}+\mathrm{C}$ content of deoxyribonucleic acid by highperformance liquid chromatography. Int J Syst Bacteriol 39, 159-167.

Newman, D. K., Kennedy, E. K., Coates, J. D., Ahmann, D., Ellis, D. J., Lovley, D. R. \& Morel, F. M. M. (1997). Dissimilatory arsenate and sulfate reduction in Desulfotomaculum auripigmentum sp. nov. Arch Microbiol 168, 380-388.

Ramamoorthy, S., Sass, H., Langner, H., Schumann, P., Kroppenstedt, R. M., Spring, S., Overmann, J. \& Rosenzweig, R. F. (2006). Desulfosporosinus lacus sp. nov., a sulfate-reducing bacterium isolated from pristine freshwater lake sediments. Int J Syst Evol Microbiol 56, 2729-2736.

Robertson, W. J., Bowman, J. P., Franzmann, P. D. \& Mee, B. J. (2001). Desulfosporosinus meridiei sp. nov., a spore-forming sulfatereducing bacterium isolated from gasolene-contaminated groundwater. Int J Syst Evol Microbiol 51, 133-140.

Spring, S. \& Rosenzweig, R. F. (2006). The genera Desulfitobacterium and Desulfosporosinus: taxonomy. In The Prokaryotes: a Handbook on the Biology of Bacteria, 3rd edn, vol. 4, pp. 771-786. Edited by M. Dworkin, S. Falkow, E. Rosenberg, K. H. Schleifer \& E. Stackebrandt. New York: Springer.

Stackebrandt, E., Spröer, C., Rainey, F. A., Burghardt, J., Päuker, O. \& Hippe, H. (1997). Phylogenetic analysis of the genus Desulfotomaculum: evidence for the misclassification of Desulfotomaculum guttoideum and description of Desulfotomaculum orientis as Desulfosporosinus orientis gen. nov., comb. nov. Int J Syst Bacteriol 47, 1134-1139.

Stackebrandt, E., Schumann, P., Schüler, E. \& Hippe, H. (2003). Reclassification of Desulfotomaculum auripigmentum as Desulfosporosinus auripigmenti corrig., comb. nov. Int J Syst Evol Microbiol 53, 1439-1443.

Thompson, J. D., Gibson, T. J., Plewniak, F., Jeanmougin, F. \& Higgins, D. G. (1997). The CLUSTAL_X windows interface: flexible strategies for multiple sequence alignment aided by quality analysis tools. Nucleic Acids Res 25, 4876-4882.

Vatsurina, A., Badrutdinova, D., Schumann, P., Spring, S. \& Vainshtein, M. (2008). Desulfosporosinus hippei sp. nov., a mesophilic sulfate-reducing bacterium isolated from permafrost. Int J Syst Evol Microbiol 58, 1228-1232.

Wagner, M., Roger, A. J., Flax, J. L., Brusseau, G. A. \& Stahl, D. A. (1998). Phylogeny of dissimilatory sulfite reductases supports an early origin of sulfate respiration. J Bacteriol 180, 2975-2982.

Wayne, L. G., Brenner, D. J., Colwell, R. R., Grimont, P. A. D., Kandler, O., Krichevsky, M. I., Moore, L. H., Moore, W. E. C., Murray, R. G. E. \& other authors (1987). International Committee on Systematic Bacteriology. Report of the ad hoc committee on reconciliation of approaches to bacterial systematics. Int J Syst Bacteriol 37, 463-464.

Widdel, F. \& Bak, F. (1992). Gram-negative mesophilic sulfatereducing bacteria. In The Prokaryotes, 2nd edn, vol. 4, pp. 3352-3378. Edited by A. Balows, H. G. Trüper, M. Dworkin, W. Harder \& K. H. Schleifer. New York: Springer.

Wiegel, J. (1981). Distinction between the Gram reaction and the Gram type of bacteria. Int J Syst Bacteriol 31, 88. 